\title{
Waste management in a university campus
}

\author{
İbrahim Uyanık ${ }^{1,2 *}$, Oktay Özkan ${ }^{1,2}$, Hamdi Mıhçıkur ${ }^{1}$ \\ ${ }^{1}$ Faculty of Engineering, Department of Environmental Engineering Erciyes University, Turkey \\ ${ }^{2}$ Research and Application Centre For Environmental Problems and Cleaner Production, Erciyes University, Turkey
}

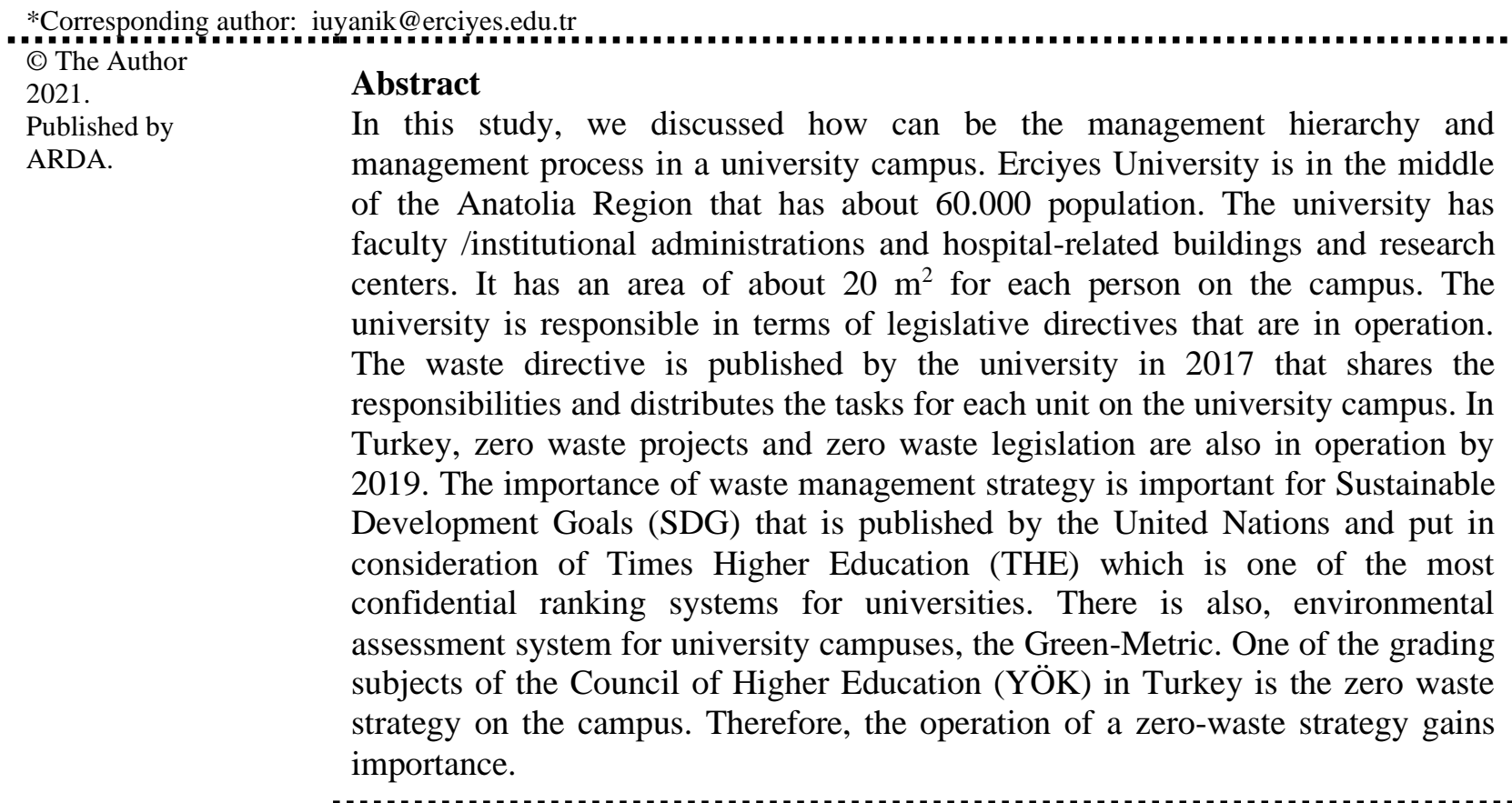

Keywords: Zero waste; University; Campus; Management

\section{Introduction}

Zero waste is a defined target that covers recycling, preventing waste, making resources more efficient, reducing the amount of waste generated, the effective establishment of the collection system, and recovery of waste as a waste prevention approach [1]. With the high acceleration in the world population, industry and the development of the economy have also increased consumption. This situation also increased the need for our limited resources and our need to use our natural resources more efficiently. In Turkey, therefore, the government improved a strategy targeting zero waste all around Turkey, starting firstly in the Environment and Urbanism Ministry and in the Presidential Complex of Turkey [2]. Zero waste regulation is published in Turkey in July of 2019 [3]. This regulation pushes the municipalities, governmental institutions, and universities to convert waste management strategies to zero waste strategy. Universities and their departments in Turkey have lots of responsibilities in terms of environmental and waste management and have many regulations (zero waste, waste management, hazardous waste, waste batteries, medical waste, excavation wastes, etc.). Also, universities are attending ranking systems that include waste and other environmental management strategies such as Times Higher Education (THE) Sustainable Development Goals (SDG) and Green Metric [4]. While SDG aims at lots of problems the Earth is facing, Green Metric mostly focused on environmental parameters such as water and waste management, setting and infrastructure, and energy. In this study; waste management strategies are discussed with the current legislations and ranking systems at university campuses in Turkey.

This work is licensed under a Creative Commons Attribution License (https://creativecommons.org/licenses/by/4.0/ ) that allows others to share and adapt the material for any purpose (even commercially), in any medium with an acknowledgement of the work's authorship and initial publication in this journal. 


\section{Materials and method}

Erciyes University has 29 academic units (faculties, colleges, institutes, etc.), 39 research centers and 70.000 people including students, academic and administrative staff [5]. In this study, waste management strategies are evaluated in the light of zero waste regulation, and other regulations in Turkey, while aiming the goals in the ranking of universities like THE-SDG and Green Metric. Erciyes University has also a waste management directive published 3 years ago.

\section{Results and discussion}

\subsection{Erciyes University waste management directive}

Erciyes University's waste management directive has a management hierarchy as shown in Fig. 1. In this, the main coordination is operated by Environmental Problems and Cleaner Production Research Center. There are responsible personals in departments and other research centers. There are also responsible personals in subdivisions in these coordination units.

\section{Rector}

Erciyes Univ. Waste Coordination

Waste Management Unit (Research Center)

Waste Coordination Unit (Department)

Unit Waste Liable (Division)

Figure 1. Erciyes University waste management hierarchy

\subsection{University rankings, green metric and THE-SDG}

Erciyes University is 3rd in 2019 Green Metric in Turkey and 133 in total. Most of the points for the green metric are coming from educational activities and water management (79\% and $75 \%$ to maximum points, respectively) while the least point is coming from waste and energy and climate change (50 and 57\%, respectively). Fig. 2 showed for each category that the green metric rankings are calculated. These results showed that it has a capacity in terms of waste management in the university [6].

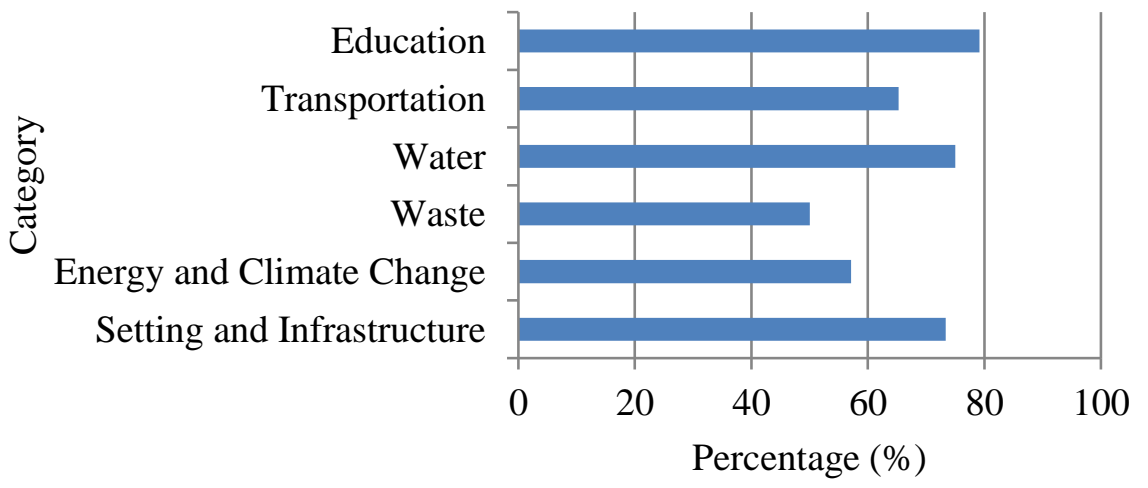

Figure 1. Green metric performance of Erciyes University

THE-SDG has several environmental goals to reach such as clean water and sanitation, affordable and clean energy, responsible consumption and production, sustainable cities and communities, and climate action. Erciyes University ranked between 101-200 ranges in all universities while it is $7^{\text {th }}$ in Turkish universities. Although the ranking details were not known, the range it has implies that a lot of actions could be taken (Table 1). 
Table 1. Erciyes University SDG rankings

\begin{tabular}{cll} 
SDG No & Sustainable Development Goal (SDG) & Rank \\
\hline 3 & Good Health and Wellbeing & $101-200$ \\
4 & Quality Education & $201-300$ \\
5 & Gender Equality & $101-200$ \\
8 & Decent Work and Economic Growth & $101-200$ \\
9 & Industry, Innovation and Infrastructure & 81 \\
10 & Reduced Inequalities & $201+$ \\
11 & Sustainable Cities and Communities & $101-200$ \\
12 & Responsible Consumption and Production & 88 \\
13 & Climate Action & $101-200$ \\
16 & Peace, Justice and Strong Institutions & $101-200$ \\
17 & Partnership for the Goals & $101-200$ \\
\hline
\end{tabular}

\subsection{Zero waste regulation in Turkey}

Zero waste regulation was published in July of 2019 and it had policies to prevent and reduce the amount of waste. Zero waste regulation expectations for universities are:

- To collect all types of wastes separately and properly,

- Education, and

- Composting.

Zero waste certification award is given to universities who; i) reduce the wastes by $15 \%$, ii) other activities to prevent and reduce the wastes [3]. It is important to collect data and make waste amount inventory to manage and calculate the waste minimization, reduction, and prevention. In this manner, education activities are important for the proper waste separation. One of the grading subjects of the Council of Higher Education (YÖK) in Turkey is the zero waste strategy on the campus since universities in Turkey graded as a "research university". If the zero waste strategy is good for a university, it is a plus for selection as a research university in Turkey.

\section{Conclusion}

Since Erciyes University is like a big district that has a population of more than 60.000 daily, it is very hard to put new rules for waste management and following the new rules without any qualified personals. At Erciyes University, recyclable wastes are now separated and collected by municipalities. Medical wastes are managed and sterilized properly. There are individual initiatives to make compost and worm manure productions. However, all the wastes like dining and cafeteria wastes are not converted to any useful products like biogas or compost.

\section{References}

[1] B. .A.G., "The strategic function of quality in the management of innovation," Total Quality Management , vol. 13, no. 2, pp. 195-205, 2002.

[2] C. M. C., L. M. Ellram, J. T. Gardner and A. M. Hanks, "Meshing Multiple Alliances," Journal of Business Logistics, vol. 18, no. 1, pp. 67-89, 1997.

[3] L. Londe and B. J., "Supply Chain Management: Myth or Reality," Supply Chain Management Review, vol. 1, pp. 6-7, 1997.

[4] J. T. Mentzer, W. D. Witt, J. S. Keebler, S. Min, N. W. Nix, C. D. Smith and Z. G. Zacharia, "Defining Supply Chain Management," Journal of Business Logistics, vol. 22, no. 2, pp. 1-25, 2001.

[5] W. C. Copacino, "Supply Chain Management ; The Basics and Beyond," Boca Raton, FL: St. Luice Press/ APICS Series on Resource Manaement, p. 5, 1997.

[6] R. Amit and C. Zott, "The fit between product market strategy and business model: implications for firm performance," Strategic Management Journal, vol. 29, pp. 1-26, 2008.

[7] J. D. Wisner, "A Structural Equation Model of Supply Chain Management Strategies and Firm Performance," Journal of Business Logistics, vol. 24, no. 1, pp. 1-26, 2003. 
[8] A. Desphande, "Supply Chain Management Dimensions, Supply Chain Performance and Organizational Performance: An Integrated Framework," International Journal of Business and Management, vol. 7, no. 8, pp. 2-19, 2012.

[9] S. M. Wagner and C. Bode, "An empriical investigation into supply chain vulnerability," Journal of Purchasing and Supply Management, vol. 12, pp. 301-312, 2006.

[10] D. Y. Hamel, "Alliance Advantage," Harvard Business School Press, 1998.

[11] R. T. Rust, C. Moorman and P. R. Dickson, "Getting Return on Quality: Revenue, Expansion, Cost Reduction, or Both?," Journal of Marketing, vol. 66, pp. 7-24, 2002.

[12] L. A., "Trial by fire: a blaze in Albaquareque sets sets off a major crisis for cell-phone giants," Wall Street Journal, 2001.

[13] F. Wu, S. Yeniyurt, D. Kim and S. T. Cavusgil, "The impact of information technology on supply chain capabilities and firm performance: A resource-based view," Industrial Marketing Management, vol. 35, pp. 493-504, 2006.

[14] N. Paskin, "Toward Unique Identifiers," Proceedings of the IEEE, vol. 87, no. 7, pp. 1208-1227, 1999.

[15] F. Ellis, "Household Strategies and Rural Livelihood Diversification," The Journal of Development Studies, pp. 2-3, 2007.

[16] A. Hargadon and R. I. Sutton, "Technology Brokering and Innovation in a Product Development Firm," Administrative Science Quarterly, vol. 42, no. 4, pp. 716-749, 1997.

[17] B. Anderton, "Innovation, product quality, variety, and trade performance: an empirical analysis of Germany and the UK," Oxford Economic Papers, vol. 51, pp. 152-167, 1999.

[18] K. P., "Differences in income elasticities and trends in real exchange rates," European Economic Review, vol. 33, pp. 1031-54, 1989.

[19] G. G. and H. E., "Technology and trade," Handbook of International Economics, vol. 3, 1995.

[20] K. P., "New theories of trade among industrial countries," The American Economic Review, Papers and Proceedings, vol. 73, pp. 343-7, 1983.

[21] A. Wieland, R. B. Handfield and C. F. Durach, "Mapping the Landscape of Future Research Temes in Supply Chain Management," Journal of Business Logistics, vol. 37, no. 3, pp. 205-212, 2016.

[22] C. Freeman, "The Economics of Industrial Innovation," 2009.

[23] B. Živanić, Na oglase za zapošljavanje vozača više se niko ne javlja, Banja Luka: Nezavisne novine, September, 2018.

[24] N. novine, Tražili 400, našli dva radnika, Banja Luka: Nezavisne novine, December, 2017.

[25] D. W.W, in Biostatistics: a foundation for analysis in the health sciences, 1999, pp. 324-326.

[26] M. D. C., in Introduction to statistical quality control, 2009.

[27] B. Durakovic, "Design of Experiments Application, Concepts, Examples: State of the Art," Periodicals of Engineering and Natural Scinces, vol. 5, no. 3, p. 421-439, 2017.

[28] N. J. and P. E.S., "On the use and interpretation of certain test criteria for purpose of statistical inference," Biometrika, vol. 20A, pp. 175-240, 1928.

[29] D. O.J., "Multiple Comparison Among Means," I Am Stat Assoc, vol. 56, pp. 52-64, 1961,.

[30] S. D.L. and N. G.R., "Correction for Multiple Testing: Is There a Resolution?," Chest, vol. 140, pp. 16$18,2011$.

[31] A. RA, "When to use the Bonferroni corrrection," Ophthalmic Physial Opt, vol. 34, pp. 502-508, 2014.

[32] B. S. a. I. Business Models, "David J. Teece," Long Range Planning, vol. 43, pp. 172-194, 2010.

[33] R. Rosenbloom and W. Spencer, "Engines of Innovation: Industrial Research at the end of an Era," Harvard Business School Press, 1996.

[34] H. Chesbrough and R. S. Rosenbloom, "The role of business model in capturing value from innovation: evidence from Xerox Corporation's technology spin-off companies," Industrial and Corporate Change, vol. 11, no. 3, pp. 539-555, 2002.

[35] S. Streukens, S. Hoesel and K. Ruyter, "Return on marketing investments in B2B customer relationships: 
A decision-making and optimization approach," Industrial Marketing Management, vol. 40, no. 1, pp. 149-161, 2011.

[36] D. C. Montgomery, Introduction to statistical quality control, 2009.

[37] "Statsoft," [Online]. Available: http://www.statsoft.com/Textbook/Multiple-Regression. [Accessed May 2018].

[38] D. C. Montgomery and G. C. Runger, Applied Statistics and Probability for Engineers, Willey, 2005. 